\title{
Könnyen érthető kommunikáció értelmi sérült személyekkel. A mondatok használatának vizsgálata könnyen érthető információkat tartalmazó doku- mentumokban
}

\begin{abstract}
A tanulmány középpontjában a könnyen érthető kommunikáció áll, melynek alkalmazása és felhasználása folyamatos monitorozást igényel annak érdekében, hogy minél eredményesebb lehessen. Az eredményességet nem csupán a már elkészült könnyen érthetö dokumentumok lektorálása szolgálja, hanem ezen dokumentumok alapját képező szabályrendszerek vizsgálata, finomhangolása is szükségszerü.

A könnyen érthető kommunikációról, annak szabályrendszereiről és célcsoportjának mondathasználati jellemzöiröl szóló rövid elméleti összefoglaló után négy, az Inclusion Europe által kiadott „Európa nekünk” címü könnyen érthetö hírlevelének mondatai kerülnek górcső alá.

Az elméleti jellegủ kutatómunkában az Inclusion Europe „Információ mindenkinek - A könnyen érthető kommunikáció európai alapelvei" címủ szabályrendszerét alapul véve arról gyüjtünk információkat, hogy a mintául szolgáló kiadványok mondataiban a mondathasználatra vonatkozó szabályok érvényesülnek-e, illetve a mondatok alkalmazása milyen mintázatokat mutat. A szabálypontokat külön-külön áttekintve, majd azok együttes érvényesülésére fókuszálva is megvizsgáltuk a mondatokat, a szabályrendszer betarthatóságának következetességére, illetve következetlenségére utaló jeleket keresve.

Az eredmények elemzése látható tette, hogy a vizsgált kiadványok nagymértékben törekednek a szabálykövetésre, ám az attól való eltérések is jelentősek. Az eredmények alapján lehetőség nyilik a könnyen érthető mondat alkotására irányuló szabályok pontosítására és kiegészitésére.
\end{abstract}

Kulcsszavak: könnyen érthető kommunikáció, szabályrendszer, mondatok, értelmi akadályozottság

\section{BEVEZETÉS}

Jelen tanulmány fókuszában a könnyen érthető kommunikáció (továbbiakban: KÉK) mint az értelmi sérült személyek kommunikációját akadálymentesítő eszköz témaköre áll. A könnyen érthető kommunikáció létjogosultságát az értelmi sérült személyek önálló életvitelhez, önálló döntéshozatalhoz, valamint az ezen jogok gyakorlásához szükséges információhoz való hozzáférés joga indokolja. A jogaik gyakorlásával a társadalomhoz való tartozásuk megerősödik, amely jelentősen kedvez a társadalom fejlődésének mind az emberi, a szociális és a gazdasági fejlődés terén (fogyatékosságügyi ENSZ egyezmény, 2006).

A könnyen érthető információforrások tára egyre bővebb és színvonalasabb, azonban rendszerszintű, közismert, szerteágazó megjelenése még kialakulóban van (Horváth, 2020). Ahhoz, hogy a célcsoport számára rendelkezésre álló információk akadálymentesítése valóban megvalósuljon, elengedhetetlen, hogy a könnyen érthető információforrások és az azokat szabályozó rendszerek hatékonyságát rendsze- 
resen ellenőrizzük, illetve finomítsuk annak érdekében, hogy az értelmi sérült emberek igényeihez alkalmazkodva valóban célba tudjon érni az általuk közvetített üzenet.

E tanulmányban a célom, hogy közvetetten segítsem a könnyen érthető dokumentumok minél hatékonyabb elkészítését. A már korábban elkészült könnyen érthető szövegek tanulmányozásával egységes szabályrendszerük egy szegmensének megvalósulását és a megvalósulásának következetességét járom körül. A vizsgálat a kiválasztott kiadványok mondataira irányul. Feladatomnak tekintem, hogy ebben a témában egy olyan feltárást végezzek, amely alapot adhat további elméleti és gyakorlati kutatásokhoz.

Tekintettel arra, hogy a Fogyatékosság és Társadalom címü folyóirat jelen tematikus számában több cikk is foglalkozik a könnyen érthető kommunikáció fogalmával, funkcióival, célcsoportjaival, ezért az alapozáshoz szükséges e témaköröket ebben a tanulmányban nem érintem. Keszey Borbála tanulmányában kerülnek bemutatásra a jelenleg elérhető magyar nyelvű szabályrendszerek és a könnyen érthető dokumentumok készítésekor felmerülő dilemmák is. A tanulmány első felében a szabályrendszerek mondatokra vonatkozó elemeit mutatom be. Mivel a könnyen érthetö információk készítéséhez nagyon fontos, hogy minél többet tudjunk a célcsoport nyelvi szintjéröl, kitérek arra, hogy a kapcsolódó szakirodalmak szerint milyen ismereteink vannak az értelmi sérült személyek mondathasználatáról.

A tanulmány második felében négy könnyen érthető hírlevél elemzését végzem, a mondatokra vonatkozó szabályok tényleges érvényesítése szempontjából. Ismertetem a kutatási kérdéseket, majd röviden vázolom azon könnyen érthető kiadványok tartalmát, amelyek a mintát alkotják. Összefoglalom, hogy milyen folyamat vezetett el a vizsgálatok eredményeihez. Tanulmányozom, hogy a mondatalkotásra vonatkozó szabályokat hogyan alkalmazzák - először a szabályokat külön-külön áttekintve, majd azok együttes érvényesülésére fókuszálva. Külön figyelmet fordítok azokra az esetekre, amelyekben szabálytól való eltérés jelentkezik, amellyel a célom az, hogy a szabályoktól való eltérések okaira is választ találjak.

\section{A mondatokra vonatkozó szabályok}

A következőkben áttekintem, hogy a különböző magyar nyelvü szabályrendszerek milyen mondatokra vonatkozó szabályokat tartalmaznak.

$A z$ „Egyszerűen, érthetően - Útmutató a könnyen érthető kommunikáció készítéséhez" címủ kiadványban a következő mondatokra irányuló szabályokat tüntetik fel:

1. "Lehetöleg rövid mondatokat írjunk."

2. „Mondatonként egy fő gondolatot fogalmazzunk meg. Egy gondolatnál vagy témánál többet ne zsúfoljunk egy mondatba."

3. „Minden mondatot külön sorba írjunk. Ha ez nem lehetséges, a részmondatokat írjuk külön sorba. A lényeg, hogy egy-egy sorban összetartozó elemek legyenek (így az olvasás szünetei megfelelnek a természetes beszéd szüneteinek).

4. „Egy mondat mindenképpen egy oldalra kerüljön (Csató, 2002:14-17).

Olyan javaslattal is találkozhatunk, amely nem kifejezetten a mondatokra irányul, viszont befolyással lehet az írásképre: „Ne válasszunk el szavakat (Csató, 2002:17.)” Ezt a szabályt azért tartom fontosnak megemlíteni, mert a szavak elválasztása 
semmiképpen nem az olvasás természetes szünetének megfelelően szakítja meg a mondatot.

A „Hogyan készítsünk könnyen érthető segédanyagot? - Irányelvek” című kiadványban a következő mondatokra vonatkozó szabályok találhatóak:

1. „Igyekezzünk kerülni az alárendelt szerkezetü összetett mondatok használatát."

2. „Lehetöleg minden új mondatot új sorban kezdjünk."

3. „Igyekezzünk rövid mondatokat alkalmazni. Ez megoldható például úgy, hogy egy gondolatot egy mondatban mondunk el" (Gruiz, é.n.:2-5.).

Ez az útmutató is javasolja a szavak elválasztásának elkerülését (Gruiz, é.n.).

Az „Információ mindenkinek - A könnyen érthető kommunikáció európai alapelvei” címủ kiadványban a mondatokra irányuló szabályoknak külön fejezetet szenteltek:

1. „Minden mondatot kezdjünk új sorban.”

2. „Használjunk rövid mondatokat. Rövid lesz a mondatunk, ha egy mondatba csak egy gondolatot írunk; és mielőtt új gondolatba kezdünk, lezárjuk a mondatunkat, vessző és kötőszavak használata helyett."

3. „Ha lehet, 1 mondatot 1 sorba írjunk. Ha egy mondatot 2 sorba kell írnunk, ott vágjuk ketté, ahol szünetet lehet tartani az olvasásban."

4. „Inkább pozitív tartalmú mondatokat használjunk, a negatív tartalmú helyett. Például ez egy pozitív tartalmú mondat: Itt kell maradnod addig, amíg a találkozó véget nem ér. Ez pedig egy negatív tartalmú mondat: A találkozó végéig nem mehetsz el."

5. „Kerüljük a szavak elválasztását. A sor végén, kötőjellel elválasztott szavak nem könnyen érthetőek" (Inclusion Europe \& ÉFOÉSZ, 2009: 11-17.).

A három szabályrendszer egyhangúan javasolja a mondatok rövidségét, az új mondatok új sorban való kezdését és a szóelválasztás kerülését. A felsorolt szabályok jól követhetőek, megfelelő rugalmasság mellett betarthatóak. Azonban előfordulhat, hogy az alkalmazásukkal olyan problémát okozunk, amely miatt esetleg új szabályra lehet szükség. Például az új mondatok új sorba írása a szöveg hosszúságának növelését eredményezheti, a hosszú szöveg pedig nehezíti a követhetöséget, érthetőséget. Ennek a problémának az eshetőségét az „Egyszerüen, érthetően - Útmutató a könnyen érthető kommunikáció készítéséhez” és az „Információ mindenkinek - A könnyen érthető kommunikáció európai alapelvei” című kiadvány is megemlíti. llyen esetben mindkét útmutató a szöveg több rövidebb részre osztását tanácsolja (Csató, 2002; Inclusion Europe \& ÉFOÉSZ, 2009).

\section{A mondatok használata értelmi sérült személyeknél}

A közlönek a könnyen érthető üzenetét az értelmi sérült személy nyelvi kompetencia-szintjéhez igazodva kell létrehoznia, melyhez elengedhetetlen, hogy a közlő ismerje a befogadó nyelvi kompetenciájának jellemzőit. Ha tudjuk, hogy kinek készítjük a tartalmat, akkor ezek a jellemzők könnyen megismerhetők. Gyakori azonban, hogy nincs elég konkrét információnk a befogadók nyelvi kompetenciájáról. Ilyenkor az üzenetet azon előzetes ismeretek alapján tudjuk kódolni, amelyeket az általunk elképzelt célcsoport nyelvi kompetenciájáról korábban szereztünk (Horváth, 2019b). Ez azt jelenti, hogy az értelmi sérült személyek nyelvi kompetenciáinak általános 
jellemzőire érdemes fókuszálni. Témaválasztásomhoz kapcsolódva jelen fejezetben a mondatok olvasásával összefüggö, létező ismeretekre fókuszálok.

Az értelmileg akadályozott személyek viszonylag jó mechanikus emlékezettel rendelkezhetnek, melynek köszönhetően az olvasás technikáját el tudják sajátítani. Ugyanakkor a szöveg hibátlan elolvasása nem garantálja azt, hogy az olvasó meg is érti a szöveg lényegét. A mondatok olvasása során a szavakat és azoknak jelentését meg kell jegyezni. Gyakori probléma, hogy a lassú olvasási tempó miatt sok idő eltelik a következő szó elolvasásáig, ezért a már addig olvasott szavakat elfelejthetik. A felejtés oka azonban nemcsak a lassú tempó, hanem a munkamemória alacsonyabb kapacitása is. Az értelmi sérült személyekre jellemző lehet az alacsony koncentrációs képesség, az ingadozó figyelem, illetve a lényegre való fókuszálás nehézsége. A célcsoport tagjai számára a szövegben való tájékozódás, a balról jobbra, fentről lefelé való haladás nagyobb erőfeszítést igényel (Lányiné, 2017; Mede, 2010; Szabó, 2006). Ezeket a nehézségeket súlyosbítaná az, ha az olvasó előtt hosszú mondatok sorakoznának. Ezzel szemben a rövid mondatok kevésbé terhelik a munkamemóriát, a koncentrációt és a tájékozódást. A mondatok hosszúsága meghatározza a sor hosszúságát is. Fontos tehát megtalálnunk azt a megfelelö mondat- és sorhosszúságot, amely után a következő sor elejére könnyedén vissza lehet találni (Horváth, 2019b).

A tapasztalatok szerint a mondatok olvasása során gondot okozhat felismerni a szavak között lévő grammatikai viszonyokat. A szöveg olvasása során pedig a mondatok közötti összefüggés észlelése okozhat nehézséget. Segíti mind a mondatok, mind a szöveg értelmezését, ha a tartalomhoz szorosan kapcsolódó, magyarázó erejü képeket, adott esetben eseményképeket kapcsolunk (Szabó, 2006).

Láthatjuk tehát, mennyire fontos, hogy a közlönek hiteles ismeretei legyenek a befogadó nyelvi kompetenciájának jellemzőiről. Az információhoz való hozzáférés nemcsak a befogadó adottságaitól és készségeitől függ, hanem attól is, hogy a közlő mennyire tud igazodni a befogadó nyelvi szintjéhez (Horváth, 2020).

\section{A VIZSGÁLAT}

Fontos, hogy a könnyen érthető üzenet készítését támogató szabályrendszerek tudományos bizonyítékon alapuljanak.

\section{Kutatási kérdések}

Arra keresem a választ, hogy a vizsgált magyar nyelvü, könnyen érthető kiadványokban az alkotók hogyan érvényesítik a szabályrendszer mondatokra irányuló útmutatásait.

1. A vizsgált dokumentumban az alkalmazott szabályrendszerben rögzített, mondatokra vonatkozó szabályoknak megfelelöen történik-e a mondatok alkotása?

2. Amennyiben a vizsgált dokumentumban az alkalmazott szabályrendszerben rögzített, mondatokra vonatkozó szabályoktól való eltérés tapasztalható, akkor az eltérésben felfedezhető-e hasonlóság, illetve következetesség? 
3. Amennyiben a vizsgált dokumentumban a szabályrendszerben rögzített, mondatokra vonatkozó szabályoktól való eltérések történnek, indokoltnak tünnek-e az eltérések?

4. Amennyiben a vizsgált dokumentumban a szabályrendszerben rögzített, mondatokra vonatkozó szabályoktól való eltérések történnek, mivel magyarázható az eltérés?

5. Milyen jellegzetességeket lehet megfigyelni a vizsgált dokumentumban megfogalmazott mondatok esetében?

\section{A mintához választott kiadványok}

A vizsgálathoz a nem valószínűségi mintavételi eljárások közül a szakértői mintavételi eljárást, valamint a véletlenszerű mintavételi eljárást választottam. $A$ könnyen érthető információforrások közül olyan publikációkra esett a választásom, amelyek a jelenlegi legfrissebb és leginkább alkalmazott, magyar nyelven elérhető szabályrendszer útmutatása alapján készültek el. Ez az „Információ mindenkinek - A könynyen érthető kommunikáció európai alapelvei” szabályrendszer. Az ilyen típusú kiadványok közül véletlenszerüen az Inclusion Europe által kiadott „Európa Nekünk” című hírlevél négy 2019-es számát emeltem be a vizsgálatba. Azért éppen ezeket választottam, mert a szabályrendszert is ez a szervezet alkotta, így joggal feltételezhető, hogy a szabályrendszer alkotójának képviselői betartják a saját szabályrendszerüket. A minta nagyságára és kiválasztásának speciális szempontjaira figyelemmel ezek a kutatási eredmények természetesen nem lesznek általános érvényűek, azonban egyes tendenciák mégis kirajzolódnak.

Az „Európa Nekünk” célja, hogy az önérvényesítéssel kapcsolatos európai híreket közölje. A kiadványok szerkezeti felépítése hasonló. Mind a négy szám tartalomjegyzékkel és egy bevezető, a hírlevél fő témáit összefoglaló résszel kezdődik. A fő részben fejezetekre bontva fejtik ki az aktuális témákat, ezeket gyakran interjúk színesítik. A kiadványok mindegyikében fellelhető a dokumentum végén található Magyarázatok című fejezet, ahol a szövegben szereplő nehezen érthető szavak, kifejezések magyarázatát olvashatjuk. A szövegek könnyen érthetőségét minden oldaIon magyarázó képekkel támogatják.

\section{Európa Nekünk - Most mi is szavazunk!}

A dokumentum a 2019-ben elsőként kiadott „Európa Nekünk” hírlevél. A „Most mi is szavazunk!" alcímet viseli, amely utal a kiadvány fő témájára, a 2019-es európai parlamenti választásra, az értelmi sérült személyek szavazati jogára és a választáshoz való hozzáférésre (Inclusion Europe, 2019a).

\section{Európa Nekünk - Europe in Action konferencia Litvániában}

A kiadvány az „Európa Nekünk” 2019-ben kiadott második száma. A fő témái a Litvániában megtartott „Europe in Action” konferencia, a 2019-es európai parlamenti választások, illetve a European Platform of Self Advocacyben (EPSA, Önérvényesítők Európai Platformja) történő elnökválasztás (Inclusion Europe, 2019b). 


\section{Európa Nekünk - Különszám a Halljátok a hangunkat címü konferenciára: Számít a hangunk!}

Ez a különszám a kiadvány megjelenését követően megtartott „Halljátok a hangunkat" című konferencia alkalmából készült. Annak okán, hogy ezt az eseményt önérvényesítők számára rendezték, a hírlevél ezen különszáma önérvényesítőkkel készített interjúkat tartalmaz; érintve az élettörténeteiket, a saját életük adta lehetöségeiket és korlátaikat (Inclusion Europe, 2019c).

\section{Európa Nekünk - Akkor lesz inklúzió, ha kiállunk magunkért!}

A kiadvány fő témája az EPSA által szervezett „Halljátok a hangunkat” című konferencia, emellett tájékoztatást nyújt a biztonságos internethasználatról és a fogyatékos gyermekek intézményi kitagolásáról is. Két interjút is tartalmaz, amelyek értelmi sérült személyek életéröl és munkájáról szólnak (Inclusion Europe, 2019d).

\section{Alkalmazott módszerek}

Az általam vizsgált témában korábban nem történt kutatás. Ezért ez a vizsgálat egyszerre elméleti és gyakorlati jellegű kutatómunka. Reményeim szerint általa betekintést nyerhetünk a szabályrendszerekben található szabályok betartásának világába. A kutatás eredményei alapján lehetőségünk nyílik mérlegelni a vizsgált szabály észszerüségét. Felmerülhet a szabályok módosításának, pontosításának vagy kiegészítésének igénye.

Szisztematikusan kiválogattam a szabályok közül a mondatalkotásra vonatkozó szabályokat. Ezek mindegyikének az érvényesülését ellenőrzöm a vizsgált négy kiadványban:

1. Az új mondat új sorban kezdődik.

2. A mondat egy gondolatból áll.

3. A mondatot egy sorban írták.

4. A mondat pozitív tartalommal bír.

5. A mondat kerüli a szavak elválasztását.

A fentieket két olyan szemponttal egészítettem ki, amelyek nincsenek benne a szabályrendszerekben:

1. Rövid mondatokat alkottak.

2. Ha a mondatot két vagy több sorban írták, akkor ott szakították-e meg, ahol olvasási szünetet lehet tartani.

Vizsgálatukat mégis szükségesnek ítéltem meg. Ennek indoklását „A vizsgálat eredményei" fejezetben fejtem ki.

Minden kiadványból a bevezető résztől a befejező, Magyarázatok címü fejezet végéig az összes mondatot listáztam először egy Word-dokumentumban, majd az eredmények számszerűsíthetősége érdekében áttettem a listát egy Excel-táblázatba. Minden mondatot egyenként vizsgáltam az összes itt felsorolt szempont szerint. 


\section{A VIZSGÁLAT EREDMÉNYEI}

\section{A szabályok érvényesülésének bemutatása, értékelése és elemzése}

Az alábbi fejezetben - sorra véve a mondatokra vonatkozó szabályokat - bemutatom, hogy a mintában szereplő kiadványokban hány mondatot találtam, hány mondat nem követte a szabályt, illetve hány mondat kompenzálta a szabály megszegését más szabály követésével.

\section{Az új mondat új sorban kezdődik?}

A négy megvizsgált kiadvány bevezető részétől a befejező Magyarázatok című fejezet végéig tartó tartománya összesen $1317 \mathrm{db}$ mondatot tartalmaz. Ebböl $1315 \mathrm{db}$ mondat új sorban kezdődik, és csak 2 nem. A két nem új sorban kezdődő mondatra jellemző, hogy pár szóból állnak és rövidek. Elképzelhető, hogy ezek a mondatok a rövidségük miatt kevésbé észlelhetők különálló mondatként a szövegben, feltehetöleg ezért történt a sorváltás elmulasztása. Nem találtam egyéb olyan tényezőt, amely által ezek a szabálytalanságok indokolttá válhatnának.

\section{Rövid-e a mondat?}

Az útmutató egy fontos szabálya az, hogy rövid mondatokat használjunk. Ezúttal felmerül a kérdés, hogy mely mondatokat tekinthetjük rövidnek. A szabályrendszer ehhez igyekszik segítséget nyújtani azzal a meghatározással, hogy ha a mondat egy gondolatot tartalmaz, akkor rövid lesz. Azonban azt gondolom, hogy a gondolatok száma mellett más tényező is befolyásolhatja a mondatok hosszát, például a szavak hossza vagy egyes felsorolások, hiszen hosszú szavak vagy terjedelmes felsorolások az egy gondolatból álló mondatokban is előfordulhatnak. Ebből kiindulva szükségesnek tartottam külön vizsgálni azt, hogy a mondatok egy gondolatból állnak-e, illetve, hogy a mondatok a szubjektív megítélésem szerint rövidek-e. Ez utóbbi minősítések, besorolások a mondat terjedelmére vonatkoznak. A terjedelmet illetően nem határoztam meg szószámokra vagy karakterszámokra vonatkozó intervallumot, hanem a mondat egy lendülettel való elolvasása volt az irányadó. Lendület alatt ebben a tanulmányban a kutató lendületét, olvasási sebességét értem. Nyilvánvaló, hogy ez nem egy objektív kategória, hiszen a lendület az olvasó számos képességétől függ. A négy kiadványban található mondatok közül 1041 db mondatról állapítottam meg, hogy a terjedelme rövid, amely 79 százalékot jelent. A rövid mondatok aránya tehát magas, viszont a 21 százalékot jelentő 276 db hosszúnak ítélt mondat lényegesen több, mint az egynél több gondolatot tartalmazó mondatok száma. Ebből arra következtethetünk, hogy a mondatok nem minden esetben válnak röviddé kizárólag azáltal, hogy csak egy gondolatot fogalmazunk meg bennük. Ez esetben is elöfordulhatnak olyan, a mondatalkotásra vonatkozó szabályoktól eltérő megoldások, amelyre igazán nem találunk indokot, viszont a mondatok hosszúságára hatást gyakorló körülmények magyarázatot adhatnak az eltérésekre. Ennek összefüggéseit szintén 
„Az eredmények bemutatása, elemzése és értelmezése a szabályok együttes érvényesülésére fókuszálva" című fejezetben fejtem ki.

\section{Egy mondat egy gondolatból áll?}

A mondatok vizsgálata során felmerült a kérdés, hogy mi számít egy gondolatnak, ugyanis az útmutatóból nem tudhatunk meg erre vonatkozó információt. A gondolat a „nagy egészből” egy egység, a gondolatmenet építőköve, amely tovább nem bontható (Keszler \& Lengyel, 2019). Így az elemzés során a mondatot az esetben ítéltem egy gondolatot tartalmazó mondatnak, ha nem volt tovább bontható olyan önálló tartalmi egységekre, amelyek önálló mondatot, illetve tagmondatot tudnának képezni. Ez alapján a négy kiadvány 1317 db mondata közül 1150 db mondat egy gondolatból áll, amely 87,3 százalékot jelent. Ez az igen magas érték rámutat a szabály követhetőségére, azonban mindenképpen figyelembe kell venni a 12,7 százalékot kitevő $167 \mathrm{db}$ mondatot. Megfigyelésem szerint a szabályt megszegő mondatok esetében elkerülhető lett volna a gondolatok halmozása azáltal, hogy mielőtt új gondolatba kezdünk, a mondatot lezárjuk, és új mondatban folytatjuk a következő gondolatot. Ez az irányadó meghatározás a szabályrendszerben szerepel is. Mindemellett azt gondolom, hogy az esetek egy részében sejthető, hogy milyen körülmény vezethetett a szabályszegéshez. Erre a lehetséges befolyásoló tényezőre „Az eredmények bemutatása, elemzése és értelmezése a szabályok együttes érvényesülésére fókuszálva" című fejezetben fogok kitérni.

\section{Hány sorból állnak a mondatok?}

Az 1315 db mondat közül 582 db mondat egysoros, 735 db viszont egynél több sort tesz ki. Főszabályként az útmutató az egy mondat - egy sor elvet vallja, de ettől eltérést enged adott esetben; ilyenkor azonban fontosnak tartja, hogy ott legyen sortörés, ahol olvasási szünetet lehet tartani . A két sorba írt mondatok közül 394 esetben megfelelő helyen történt a sortörés, 64 esetben pedig nem. A szabályrendszer nem tér ki azonban azokra a mondatokra, amelyek több, mint két sort tesznek ki. Az általam áttekintett négy kiadványban 277 ilyen eset fordult elö. Azt gondolom, hogy a kétsoros mondatokra vonatkozó meghatározás lényege a megfelelö, hangsúlyokat figyelembe vevő tagoltság, ezért a kettőnél több soros mondatoknál ugyanezen szempont szerint végeztem a megfigyelést, külön kigyüjtve ezeket a mondatokat. Ilyen módon az összes több sorba írt mondat közül 234 olyan mondatot találtam, amely több, mint két sorból áll, de megfelelő helyeken törik meg azokat, illetve 43 olyan mondatot számoltam össze, amelyek több, mint két sorból állnak, viszont nem megfelelő helyeken van sortörés. Megállapítható, hogy a négy megvizsgált kiadvány mondatainak 44 százaléka egysoros, míg 56 százaléka egynél több sort képez. Az egy sorba írt mondatok aránya alacsony értéket mutat. Véleményem szerint ezt a szabályt nagyon nehéz betartani. A szabályrendszer megengedő, ugyanis iránymutatást ad arra is, hogy milyen módon lehet helyesen eljárni két sorba írt mondatok esetén. Amennyiben a feltétel megvalósul, vagyis a sort ott szakították meg, ahol szünetet lehet tartani az olvasásban, akkor helyesen jártak el. Emellett a két sort képező mondatok mellett számos olyan mondat is van, amely kettőnél több sorból áll. 
Az összes megvizsgált mondat 21 százalékáról van szó, illetve az egynél több sorból álló mondatok 38 százalékáról. Ez a mennyiség számottevő. Mivel az útmutató nem tiltja a kettőnél több sorból álló mondatok alkalmazását, de nem is határoz meg konkrétan azokra irányuló szabályt, a két sorból álló mondatokhoz hasonlóan tekintettem át azokat. Ebből kifolyólag a továbbiakban e két kategóriát egy kategóriába, a több sorba írt mondatok csoportjába sorolom.

\section{A több sorba írt mondatok esetei}

Most tekintsük át, hogy a több sorba írt mondatok milyen mértékben teljesítik a meghatározott feltételt, hiszen a mondatok sormennyiségeinek szabályosságát ez mutatja meg reálisabb módon. A szóban forgó mondatok az esetek 85,4 százalékában szabályosan szerepelnek a kiadványokban, vagyis a sorokat megfelelő helyen szakították meg. 107 mondat viszont helytelen módon szakítja meg a sort, illetve sorokat. Ez az érték 14,6 százalékot jelent, amely összességében nem magas, de ezen szabálytalanságokat magyarázó indokokat nem találtam.

\section{A felsorolások esetei}

Az ellenőrzés során észrevettem, hogy a hosszúnak ítélt, illetve a többsoros mondatok között elöfordulnak pontokkal jelzett felsorolások. A négy kiadványban összesen $56 \mathrm{db}$ felsorolás található. Ezek közül $17 \mathrm{db}$ felsorolásban minden felsorolást jelző pont külön mondatot fejez ki, 39 esetben pedig minden felsorolást jelző pont az egész mondat egy-egy része. A szabályrendszer felhívja a figyelmet, hogy a veszszőkkel elválasztott, egymás mellé írt felsorolás helyett pontokat használjunk, és a felsorolás tagjait egymás alá írjuk. Az egymás alá strukturálás könnyebben olvasható, mint az egymás mellé való felsorakoztatás. Ugyanakkor az egymás alá írás megnyújtja a szöveget, és többsorossá teszi az adott mondatot. Vannak tehát olyan helyzetek, amikor nem lehet két szabályt egyszerre érvényesíteni, és választani kell közülük. Ilyenkor azt a szabályt célszerű választani, amelyik a könnyen olvashatóságot és könnyen érthetőséget jobban szolgálja. A vizsgált hírlevelek elemzésének a tapasztalatai alapján úgy vélem, hogy könnyebben olvasható az a szöveg, amelyikben a felsorolás tagjait annak ellenére egymás alá rendezzük, hogy a mondat látszólag ettől hosszabbá válik.

\section{A mondatok pozitív tartalommal bírnak?}

Az 1317 db mondat közül 1237, vagyis az összes mondat 94 százaléka pozitív tartalommal bír. $A z$ is látható, hogy a mondatok 6 százalékának (80 eset) negatív tartalma van. A szabály követése szempontjából ez egy kedvező arány, és ha figyelembe vesszük a szabálytól eltérő esetek indokoltságának arányát, az eredmény még kedvezőbbé válik. Ugyanis a 80 negatív tartalmú mondat közül 60 mondat, vagyis az esetek 75 százaléka azért rendelkezik negatív tartalommal, mert vagy egy előző mondatban megfogalmazott kérdésre adott nemleges válaszról van szó, vagy olyan igék és melléknevek tagadásáról, valamint tagadó- és fosztóképzőt tartalmazó szóról van szó, amelyek más szóval, kifejezéssel leírva bonyolultabbá válhatnak. Tehát 
a negatív tartalmú mondatok háromnegyedében indokoltnak tartom a szabálytól való eltérést. 20 mondatban viszont elkerülhetö lett volna a tartalom negatív módon való kifejezése. Például a „Tudom, hogy ez sokszor nem könnyü.” (Inclusion Europe, 2019d:14) mondatban a „nem könnyü” helyett a „nehéz” szó használata elkerülte volna a tagadást, és nem vált volna bonyolultabbá. Azonban egyes helyzetekben sejthető, hogy miért választották mégis a negatív tartalmat: a kontextus miatti árnyaltság okán. Az elöbb felhozott példamondat az értelmi sérült személyek nehezített munkavállalásának témakörében található. Ezért feltételezhetően a többségi társadalom tagjainak „könnyebb” munkavállalásával kívánták szembeállítani az értelmi sérült emberek e téren megjelenő nehézségét - a „nem könnyü” kifejezéssel. Összességében megállapítható, hogy a megvizsgált kiadványokban nem okoz jelentős problémát a negatív tartalom elkerülése.

\section{A mondatok kerülik a szóelválasztást?}

A négy megvizsgált kiadvány mondatainak szinte mindegyike kerüli a szóelválasztást, csupán egy esetben történt ilyen szabálytalanság. Ebben az egy mondatban a sor végére esett egy idegen szó, amelynek a toldalékolása kötőjel használatával történt. Ez önmagában nem indokolja az elválasztást, de elképzelhetö, hogy egy nem idegen szó esetében, ahol a kötőjel nem szükséges a toldalékoláshoz, az elválasztás gondolata kisebb eséllyel merül fel. Összességében az látható, hogy az elválasztás elkerülésére felhívó szabály könnyen betartható.

\section{Az eredmények bemutatása, elemzése és értelmezése a szabályok együttes érvényesülésére fókuszálva}

Összesítve, hogy a kiadványokban vizsgált mondatokban hány szabályt sikerült következetesen érvényesíteni, láthatjuk, hogy a szabályoktól inkább eltérő mondatok kisebb arányúak, inkább a szabályoknak megfelelő mondatok a jellemzők. Ugyan a helyesen megszakított, több sorból álló mondatok más kategóriába tartoznak, mint az egysoros mondatok, a számítás során mégis egy csoportba, a szabályt követő mondatok csoportjába tartozónak vettem őket, hogy az összesítésben megőrizzem a szabálytalanul megszakított mondatok arányát. A mondatok nagy részében a különböző szabályok követése jól tud érvényesülni egymás mellett. Sok olyan mondat van, amelyben akár kettőnél is több szabály érvényesül, és nincs olyan mondat, amelyben egyik szabályt sem tartották be.

Mint korábban említettem, egy-egy szabály megszegése esetében fontos áttekinteni, hogy van-e indok a szabálytól való eltérésre. Azt gondolom, ennek feltárását szolgálja az, ha a mondatokra vonatkozó szabályok együttes előfordulását, valamint azok egymásra való hatását figyeljük meg.

A továbbiakban a következő meghatározások együttes előfordulásának eseteit fejtem ki:

1. A mondat egy gondolatból áll.

2. A mondat rövid - szubjektív megítélés szerint. 
3. A mondat egysoros.

4. Ha a mondat két vagy több soros, akkor ott szakították meg, ahol szünetet lehet tartani az olvasásban.

\section{A szabályok érvényesülése az egy gondolatból álló mondatokban}

Az egy gondolatból álló mondatok több mint fele rövid és egysoros. 31 százaléka pedig szintén rövid, de több sorból áll, amelyeket megfelelően szakítottak meg. Azt is láthatjuk, hogy nagyon kevés olyan egy gondolatból álló mondat van, amelyek egy sort alkotnak, de hosszúak, vagy a sorokat szabálytalanul megszakítva több sort alkotnak és hosszúak. Tehát az egy gondolatot tartalmazó mondatokhoz szorosan kapcsolódik a rövid terjedelem, illetve az egy-vagy többsoros, de szabályosan megszakított szerkesztés. Az esetek összesen 12,6 százalékában, amikor az egy gondolatból álló mondat hosszú, akkor többnyire több sorból áll a mondat.

\section{A szabályok érvényesülése a több gondolatból álló mondatokban}

A több gondolatból álló mondatok 68,3 százaléka hosszú és többsoros, de megfelelö helyen megszakított mondat. Csupán 21,6 százaléka rövid, és azon belül is 2,4 százaléka egy sorban íródott rövid mondat. Az, hogy a mondatok több gondolatból állnak, leginkább a mondatok hosszára és sorainak számára van hatással, vagyis sok esetben hosszabbá és több sorból állóvá válik töle a mondat. Az arányok azt mutatják, hogy a sorok megfelelö helyen való megszakítása nincs szoros összefüggésben azzal, hogy a mondat több gondolatból áll.

\section{A szabályok érvényesülése a szubjektív megítélésem szerinti rövid és hosszú mondatokban}

Azoknak a mondatoknak, melyeknek terjedelmét rövidnek ítéltem meg, 55,4 százaléka egy gondolatból áll és egy sort tesz ki. Szintén nagy részük, 34 százalékuk egy gondolatból áll, és többsoros, de a sorokat megfelelő helyen szakították meg. A rövid mondatok elenyésző része, összesen 3 százaléka tartalmaz több gondolatot. Tehát a kiadványok azon mondatait találtam leginkább rövid terjedelműnek, amelyek egy gondolatból állnak, és emellett vagy egy sort képeznek, vagy pedig többet, de azokat ott szakították meg, ahol az olvasásban szünetet lehet tartani. A kiadványok mondatainak 41,5 százaléka akkor is rövid, ha több sorból áll.

A hosszú terjedelmű mondatok összesen 52,6 százaléka egy gondolatból áll. Ebböl arra következtethetünk, hogy a mondatok egy gondolatban való megfogalmazása nem feltétlen eredményez rövid mondatot. Azonban az esetek nagy részében, 85,5 százalékában a mondatok hosszúak, amikor azok többsorosak és megfelelő helyen szakították meg a sorokat. A hosszú mondatok szinte mindegyike, 99,6 százaléka több sorból áll; ugyanakkor a több sorból álló mondatok nem feltétlenül hosszúak. 


\section{A szabályok érvényesülése a több sorba írt, megfe- lelöen megszakitott mondatokban, valamint a több sorba írt, szabálytalanul megszakitott mondatokban}

A többsoros mondatoknak, függetlenül attól, hogy a soraikat megfelelő helyen szakították-e meg, több mint 60 százaléka rövid. Emellett a többsoros mondatok több mint háromnegyed része csak egy gondolatot tartalmaz, ebből 75 százalék pedig rövid is. Ebböl az látható, hogy a többsoros mondatok sok esetben röviddé válhatnak, ha csak egy gondolatot tartalmaznak. A szabályosan és szabálytalanul megszakított többsoros mondatok viszonya a többi szabállyal nagyon hasonló. Kisebb különbség, hogy míg a több sorba írt, megfelelöen megszakított sorú mondatok között van olyan, ami több gondolatból áll, mégis rövid, a szabálytalanul megszakított sorú mondatok esetén nem fordul ilyen elö. Ez a különbség azonban nem számottevő.

\section{A mondatok esetei együttesen megfigyelt szabályok alapján}

A megvizsgált kiadványok összes mondatának 71,1 százaléka tartja be valamilyen módon a jelenleg szóban forgó szabályok mindegyikét. Ebböl a legtöbb rövid, egy gondolatból áll, és egysoros, de sok olyan mondat is van, amely rövid, egy gondolatból áll, és ugyan többsoros, de azok megfelelő megszakítást kaptak.

A mondatok 2,4 százaléka több gondolatból tevődik össze, és megfelelő megszakítással többsoros. Ennek ellenére mégis rövid maradt a terjedelmük. Ez összesen 32 esetet jelent, amely az összes mondattal összevetve nem sok, de a több gondolatból álló mondatok 19 százaléka, vagyis közel egyötöde. Korábban kifejtettem, hogy az útmutató leírása szerint a mondat rövid lesz akkor, ha egy mondatba csak egy gondolatot írunk. Viszont az előbb említett eseteket figyelembe véve fennáll az a lehetőség, hogy azért fordultak elő több gondolatból álló és több sort kitevő mondatok, mert azok rövid terjedelmüek tudtak maradni.

A kiadványok összes mondatának 76,3 százaléka egy gondolatból álló rövid mondat. E kategóriának pedig 57 százaléka, vagyis több, mint a fele több sorból áll. Ez azt jelenti, hogy a mondat akkor is lehet rövid, ha egy gondolatból áll, de többsoros. Viszont az ilyen esetek 16 százalékát nem ott szakították meg, ahol szünetet lehet tartani az olvasásban, ez pedig akadályozza a könnyen érthetőséget. Ezek az eredmények arra engednek következtetni, hogy hiába valósulhat meg az, hogy az egy gondolatból, de több sorból álló mondatok rövidek maradhatnak, ha ezeknek egy része mégsem könnyen érthető, mert soraikat nem megfelelö helyen szakították meg.

A megvizsgált mondatok összesen 11 százaléka egy gondolatból áll, ezzel együtt hosszú és többsoros. Ezekben az esetekben a mondatok hosszúságát okozhatja az, hogy több sorban nyúlnak el, viszont elképzelhető, hogy azért fordultak elő ilyen mondatok, mert csak egy gondolatot tartalmaznak. Az útmutató pedig azt mondja, hogy rövid lesz a mondatunk, ha az egy gondolatot tartalmaz. Viszont ez a megvizsgált négy kiadvány azt mutatja, hogy nem feltétlen válnak röviddé az egy gondolatot 
tartalmazó mondatok. Az elemzésem szerint ennek oka vagy az emberi tévesztés lehet, vagy pedig az, hogy egy hosszú, több sorba íródott mondat is tartalmazhat csupán egy gondolatot.

\begin{tabular}{|c|c|c|}
\hline A MEGFIGYELT SZABÁLYOK & $\begin{array}{l}\text { SZABÁLYKÖVETŐ } \\
\text { MONDATOK }\end{array}$ & $\begin{array}{l}\text { SZABÁLYTÓL ELTÉRŐ } \\
\text { MONDATOK }\end{array}$ \\
\hline $\begin{array}{l}\text { Az új mondat új sorban } \\
\text { kezdődik. }\end{array}$ & $\begin{array}{l}\text { Sylvie Guillaume az Európai } \\
\text { Parlament alelnöke. }\end{array}$ & $\begin{array}{l}\text { Ez jó munkahely! Már hét éve } \\
\text { itt dolgozom. }\end{array}$ \\
\hline A mondat egy gondolatból áll. & $\begin{array}{l}\text { A konferencia a befogadásról } \\
\text { szólt. }\end{array}$ & $\begin{array}{l}\text { Odamegyek, ahová akarok, } \\
\text { azt csinálok, amit akarok, és } \\
\text { senki nem szól bele. }\end{array}$ \\
\hline A mondatot egy sorban írták. & $\begin{array}{l}\text { De sokan vannak, akik nagyon } \\
\text { nehezen találnak munkát. }\end{array}$ & $\begin{array}{l}\text { A 10. oldaltól a } 15 \text {. oldalig } \\
\text { értelmi fogyatékossággal } \\
\text { élő szülőkkel olvashattok } \\
\text { interjúkat. }\end{array}$ \\
\hline $\begin{array}{l}\text { A mondat pozitív } \\
\text { tartalommal bír. }\end{array}$ & $\begin{array}{l}\text { A Lebenshilfe egy német szó, } \\
\text { azt jelenti, hogy önsegély. }\end{array}$ & $\begin{array}{l}\text { Nem igazságos, hogy az } \\
\text { értelmi fogyatékossággal élők } \\
\text { nem tudnak szavazni. }\end{array}$ \\
\hline $\begin{array}{l}\text { A mondat kerüli a szavak } \\
\text { elválasztását. }\end{array}$ & $\begin{array}{l}\text { A Lászlóval készült interjút az } \\
\text { 24. oldalon találod. }\end{array}$ & $\begin{array}{l}\text { Új tagszervezetek is } \\
\text { csatlakoztak az Inclusion } \\
\text { Europe-hoz. }\end{array}$ \\
\hline A mondat rövid. & $\begin{array}{l}\text { Sokat vagyok Brüsszelben és } \\
\text { Strasbourgban. }\end{array}$ & $\begin{array}{l}\text { Mit lehet tenni azért, hogy } \\
\text { a komplex támogatási igényű } \\
\text { emberek is akadálymentesen } \\
\text { részt tudjanak venni } \\
\text { a találkozókon? }\end{array}$ \\
\hline $\begin{array}{l}\text { Ha a mondatot két vagy } \\
\text { több sorban írták, akkor ott } \\
\text { szakították meg, ahol olvasási } \\
\text { szünetet lehet tartani. }\end{array}$ & $\begin{array}{l}\text { Egy másik önérvényesítő azt } \\
\text { mondta, hogy nagyon szeretne } \\
\text { szavazni, mert a szavazata } \\
\text { változást hozhatna az értelmi } \\
\text { fogyatékossággal élőknek. }\end{array}$ & $\begin{array}{l}\text { A komplex támogatási igény } \\
\text { azt jelenti, hogy valakinek több } \\
\text { dologban is támogatásra van } \\
\text { szüksége. }\end{array}$ \\
\hline
\end{tabular}




\section{A MONDATOK ESETEI EGYÜTTESEN MEGFIGYELT SZABÁLYOK ALAPJÁN}

- Egy gondolatból áll,

- rövid,

- egy mondat egy sorban van leírva.

- Egy gondolatból áll,

- rövid,

- egy mondat több sorban van leírva, megfelelően megszakítva.

- Egy gondolatból áll,

- rövid,

- egy mondat több sorban van leírva, szabálytalanul megszakítva.

- Egy gondolatból áll,

- hosszú,

- egy mondat egy sorban van leírva.

- Egy gondolatból áll,

- hosszú,

- egy mondat több sorban van leírva, megfelelően megszakítva.

- Egy gondolatból áll,

- hosszú,

- egy mondat több sorban van leírva, szabálytalanul megszakítva.

- Több gondolatból áll,

- rövid,

- egy mondat egy sorban van leírva.

- Több gondolatból áll,

- rövid,

- egy mondat több sorban van leírva, megfelelően megszakítva.

- Több gondolatból áll,

- rövid

- egy mondat több sorban van leírva, szabálytalanul megszakítva.

- Több gondolatból áll,

- hosszú,

- egy mondat egy sorban van leírva.

- Több gondolatból áll,

- hosszú,

- egy mondat több sorban van leírva, megfelelően megszakítva.

- Több gondolatból áll,

- hosszú,

- egy mondat több sorban van leírva, szabálytalanul megszakítva.

\section{Példamondatok}

A közelmúltban megújult a honlapunk.

És fontos nekünk,

hogy válasszunk!

Mindannyian képesek

vagyunk választani.

A Lebenshilfe harcolt a törvény megváltoztatásáért.

Ebben a kiadványban sok cikket fogsz arról találni:

- Az európai választásokról

- szavazati jogról

- a választásokhoz való hozzáférésröl

Mit mondasz az olyan értelmi fogyatékossággal élő embereknek, hogy menjenek el szavazni?

Az EPSA közgyűlésén választották meg, júniusban.

Az Európai Unió egy csoport, aminek 28 ország a tagja.

$-$

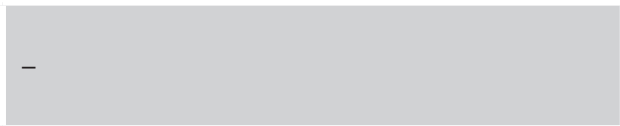

Például, hogy legyenek rámpák,

így kerekesszékkel is fel lehessen menni a színpadra.

Ha azt írod, hogy \#inclusion, és rákattintasz, meglátod

azokat az üzeneteket, amik az Inclusion Europe-hoz kapcsolódnak. 
- Egy gondolatból áll,

- rövid,

- egy mondat egy sorban van leírva.

- Egy gondolatból áll,

- rövid,

- egy mondat több sorban van leírva, megfelelően megszakítva.

- Egy gondolatból áll,

- rövid,

- egy mondat több sorban van leírva, szabálytalanul megszakítva.

- Egy gondolatból áll,

- hosszú,

- egy mondat egy sorban van leírva.

- Egy gondolatból áll,

- hosszú,

- egy mondat több sorban van leírva, megfelelően megszakítva.

- Egy gondolatból áll,

- hosszú,

- egy mondat több sorban van leírva, szabálytalanul megszakítva.

- Több gondolatból áll,

- rövid,

- egy mondat egy sorban van leírva.

- Több gondolatból áll,

- rövid,

- egy mondat több sorban van leírva, megfelelően megszakítva.

- Több gondolatból áll,

- rövid,

- egy mondat több sorban van leírva, szabálytalanul megszakítva.

- Több gondolatból áll,

- hosszú,

- egy mondat egy sorban van leírva.

- Több gondolatból áll,

- hosszú,

- egy mondat több sorban van leírva, megfelelően megszakítva.

- Több gondolatból áll,

- hosszú,

- egy mondat több sorban van leírva, szabálytalanul megszakítva.

Összes mondat száma: 1317

A mondatok esetszámai több szabály együttes megvalósulása esetén 


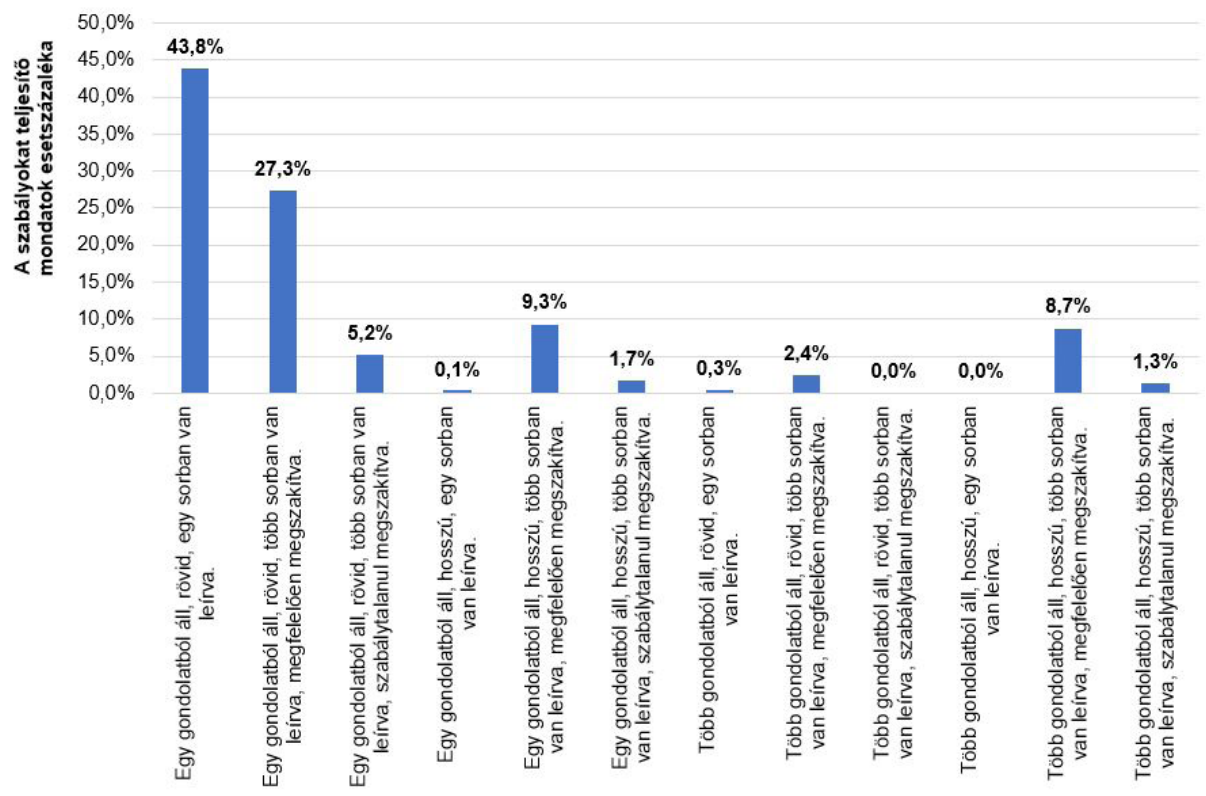

1. diagram: A mondatok eloszlása a szabályok együttes teljesítése alapján

\section{A kutatási kérdések megvitatása}

Az első kutatási kérdésem az volt, hogy a vizsgált dokumentumban az alkalmazott szabályrendszerben rögzített, mondatokra vonatkozó szabályoknak megfelelöen történik-e a mondatok alkotása. Összességében elmondható, hogy a mondatok nagyobb arányban betartják a szabályokat, mint hogy nem követik azokat. Ezek alól kivételt képez az egy sorba írt mondatok esete, ugyanis a több sorba írt mondatok inkább jellemzőek, mint az egy sorba írt mondatok. Ezt viszont igyekszik kompenzálni az az eredmény, hogy több olyan többsoros mondat van, amelynek sorait helyesen szakították meg, mint amelynek szabálytalanul. Megfigyelve a szabályok együttes érvényesülését, azt láthatjuk, hogy a mondatok nagy részében alkalmaztak helyesen egyszerre több szabályt. Az eltérések aránya ugyan nem túl magas, de az elöfordulásuk figyelemre méltó.

A második kutatási kérdésem az volt, hogy amennyiben a vizsgált dokumentumban az alkalmazott szabályrendszerben rögzített, mondatokra vonatkozó szabályoktól való eltérés tapasztalható, akkor az eltérésben felfedezhetö-e hasonlóság, illetve következetesség. A vizsgálat során háromféle hasonlóságot találtam bizonyos szabályoktól való eltérések során. Ezek a hasonlóságok jellemzően jelen vannak, de nem minden esetben fordulnak elö. Az eredmények azt mutatják, hogy a nem egy gondolatból álló mondatok többségére jellemző, hogy hosszú, többsoros mondatokat eredményeznek, melyeknek sorait ott szakították meg, ahol az olvasásban szünetet lehet tartani. Amikor a mondatok nem rövid terjedelműek, akkor a legtöbb esetben, függetlenül attól, hogy hány gondolatból állnak, több sort alkotnak, és a soraikat megfelelően szakították meg. A nem egysoros mondatok pedig a legtöbbször egy gondolatból állnak. 
A harmadik kutatási kérdésem az volt, hogy amennyiben a megvizsgált kiadványokban a mondatokra vonatkozó szabályoktól való eltérések történnek, indokoltak-e az eltérések. A többsoros, hosszú mondatok, valamint a negatív tartalommal bíró mondatok egy részében indokolt eltéréseket találtam.

A negyedik kutatási kérdésem az volt, hogy amennyiben a vizsgált dokumentumban a szabályrendszerben rögzített, mondatokra vonatkozó szabályoktól való eltérések történnek, mivel magyarázható az eltérés. Az útmutató szerint a mondatok rövidek lesznek, ha egy gondolatból állnak, viszont, ha a gondolatot csak úgy lehet megfogalmazni, hogy az több sort alkosson, akkor a mondat hosszúvá válhat. Tehát ezekben az esetekben az az eltérés oka, hogy a gondolat kifejtése csak terjedelmesen kivitelezhető. Emellett a felsorolást jelző pontokkal történő felsorolások is többsoros mondatokat eredményezhetnek, amennyiben minden felsorolást jelző pont az egész mondat egy-egy része. Viszont azok használata az útmutató szerint indokolt a könnyen érthetőség elérése érdekében. A negatív tartalommal bíró mondatok használata indokolt azokban az esetekben, amikor nemleges választ tartalmaz egy előző mondatban megfogalmazott kérdésre, illetve, ha olyan igék és melléknevek tagadásáról, valamint tagadó- és fosztóképzőt tartalmazó szóról van szó, amelyek bonyolultabbá válnának más szóval, kifejezéssel leírva.

Az ötödik kutatási kérdésem az volt, hogy milyen jellegzetességeket lehet megfigyelni a vizsgált dokumentumban megfogalmazott mondatok esetében. Az elemzés során azt találtam, hogy a kiadványok mondatainak szinte mindegyikére jellemző az új sorban történő kezdés, valamint az elválasztások kerülése.

\section{JAVASLATTÉTEL, TOVÁBBI KUTATÁSI LEHETŐSÉGEK}

Az általam vizsgált kiadványokban a szerzők tehát összességében törekedtek a mondatokra vonatkozó szabályok betartására, azonban a feltárt eltéréseket is fontos figyelembe venni. Bár a szabályrendszerek igyekeznek objektív keretet adni, mind a könnyen érthető információforrások készítésekor, mind a szabályok megvalósulásának ellenörzése során elkerülhetetlen a szubjektivitás megjelenése. Ezért úgy gondolom, hogy szükség van a szabályok megfogalmazásának pontosítására, hiszen egyes kifejezések, mint például a „rövid mondat” vagy az „egy gondolat”, szubjektíven értelmezhetőek, ez pedig akadályozhatja más szabályok betartását, ezzel együtt a könnyen érthetőséget. Léteznek olyan mondattípusok is, amelyek alkotására vonatkozó szabályt nem találunk. Meglátásom szerint érdemes lenne a szabályrendszerben olyan esetek pontosítására kitérni, amelyek során két szabály nem tud egyszerre érvényesülni.

A kutatómunkám alapján a mondatokra vonatkozó szabályok megújításához a következö javaslatokat sorakoztatom fel:

1. A szabályrendszerben a mondatok rövidségét jelenleg egy megvalósulandó feltétellel határozzák meg: egy mondatban egy gondolat legyen. A javaslatom a mondat rövidségének konkrétabb meghatározása, mérhetöbb keretek közé szorítása. Az egy mondatban megjeleníthető szavak vagy a karakterszámok felső határának megadása objektívebb, ezáltal követhetőbb feltételt kínálna. 
2. Az a meghatározás, miszerint egy mondatban egy gondolatot kell megfogalmazni, pontosítást, kiegészítést igényel. Javaslom az egy gondolatot és a több gondolatot tartalmazó mondatok legjellemzőbb példáinak felsorakoztatását.

3. A mondatok többsorosságát gyakran a pontjellel történő felsorolás eredményezi - amennyiben a felsorolást jelző pontok az egész mondat egy-egy részei. Ennek egy megoldása lehetne a pontjelzéses felsorolás e típusának tiltása. Azok az esetek továbbra is megengedettek lehetnek, amelyeknél a felsorolást jelző pontok külön mondatokat tartalmaznak.

4. Jelenleg a többsoros mondatok korlátozása és a pontjeles felsorolások engedélyezése is szerepel a szabályrendszerben, de e két meghatározás egymásra való hatása nem. Javaslom a mondatokra vonatkozó szabályok között, a többsoros mondatok esetében a pontjeles felsorolások okozta többsoros mondatok megengedését jelezni. Például: a mondat több sorból állhat, ha pontjeles felsorolást használunk. Ez a módosítás a 3. javaslatom mellett nem állja meg a helyét, a két javaslat külön-külön, „vagy-vagy” választással értelmezendő.

5. A szabályrendszer nem tiltja a kettőnél több soros mondatok használatát, de nem is tér ki arra, hogy hogyan kell azokat helyesen kivitelezni. Javaslom az egy mondatban maximum megengedett sorok számának jelzését, illetve, ha kettőnél több sor megengedett, akkor az azokra vonatkozó helyes kivitelezés meghatározását is.

A kutatásomban nem vizsgáltam a könnyen érthető mondatalkotás minden aspektusát. A szabályok további pontosításához hasznos lenne további kutatásokat végezni, amelyek a szabályrendszer finomítására vonatkozó pontosabb információkkal szolgálnak, valamint olyan gyakorlati kutatásokat is, amelyek a szabályrendszer átformált verziójának eredményességét helyezik a középpontba.

\section{Irodalom}

a Fogyatékossággal élő személyek jogairól szóló ENSZ egyezmény, 2006

Csató Zs. (szerk.) (2002). Egyszerủen, érthetően: útmutató könnyen érthető tájékoztatók készítéséhez. ÉFOÉSZ, Budapest.

Gruiz K. (évszám nélkül). Hogyan készítsünk könnyen érthető segédanyagot? - Irányelvek. Down Alapítvány, Budapest.

Horváth P. L. (2019b). A könnyen érthető kommunikáció meghatározása. Carissimi, X.2:8-10.

Horváth P. L. (2020). A könnyen érthető kommunikációs képzési programok képzésfejlesztésének története Magyarországon a fogyatékossággal élő személyek jogairól szóló ENSZ egyezmény tükrében. (Doktori értekezés.) Eszterházy Károly Egyetem Neveléstudományi Doktori Iskola, Eger.

Inclusion Europe \& ÉFOÉSZ (2009). Információt mindenkinek! A könnyen érthető kommunikáció európai alapelvei. Inclusion Europe - ÉFOÉSZ, Brüsszel - Budapest.

Inclusion Europe (2019a). Európa Nekünk - Most mi is szavazunk! Inclusion Europe, Brüsszel.

Inclusion Europe (2019b). Európa Nekünk - Europe in Action konferencia Litvániában. Inclusion Europe, Brüsszel.

Inclusion Europe (2019c). Európa Nekünk - Különszám a Halljátok a hangunkat címü konferenciára: Számít a hangunk! Inclusion Europe, Brüsszel.

Inclusion Europe (2019d). Európa Nekünk - Akkor lesz inklúzió, ha kiállunk magunkért! Inclusion Europe, Brüsszel.

Keszler B. \& Lengyel K. (2019) Kis magyar grammatika. Akadémiai Kiadó, Budapest. https://doi. org/10.1556/9789630599641

Lányiné Engelmayer Á. (2017). Intellektuális képességzavar és pszichés fejlödés. Medicina Könyvkiadó, Budapest. 
Mede P. (2010). Értelmileg akadályozott gyermekek olvasás-írás tanítása. In Radványi K. (szerk.), ¿MÁSKÉ(P)P? Intellektuális fogyatékossággal élő emberek gyógypedagógusainak tankönyve. ELTE Bárczi Gusztáv Gyógypedagógiai Kar, Budapest. 63-75.

Szabó B. (2006). Inkluzív nevelés. Ajánlások értelmileg akadályozott gyermekek, tanulók kompetencia alapú fejlesztéséhez. Szövegértés-szövegalkotás. suliNova Közoktatás-fejlesztési és Pedagógus-továbbképzési Kht., Budapest.

A szegedi Könnyen Érthető Információs Központban - többek között - könnyen érthetö kiadványokat készítünk, melyeket az alábbi logóval jelöljük meg:

Készítünk majd csak képeket, képeket és szöveget, illetve csak szöveget tartalmazó kiadványokat:

A kiadványok érthetőségét tapasztalati szakértők ellenőrzik.

Az ellenőrzés tényét az alábbi logóval jelöljük:

A kiadványokat a könnyen érthető információ készítésének szabályrendszere alapján dolgozzuk ki. A szabályrendszernek való megfelelés tényét az alábbi logóval jelöljük:
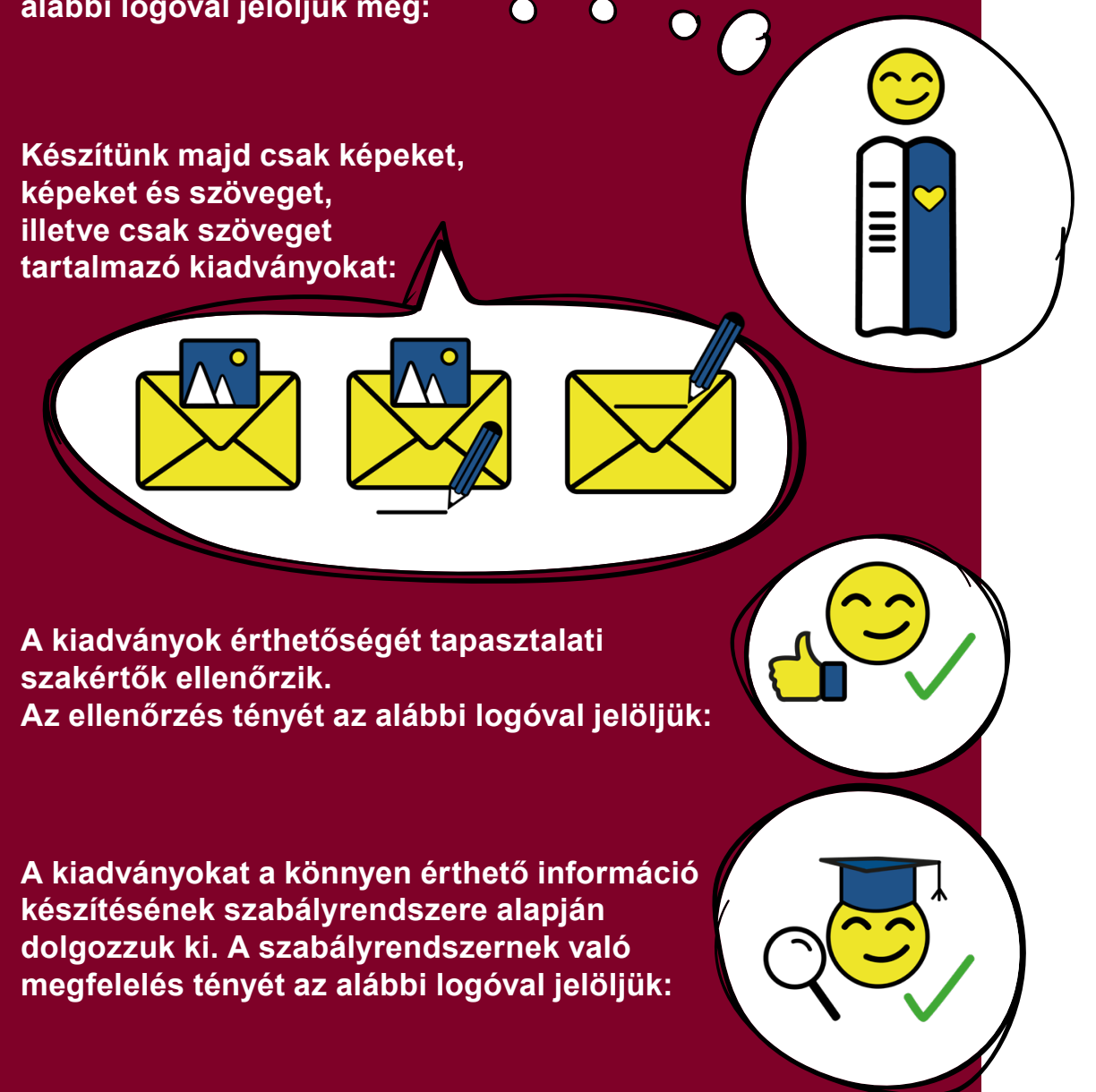

Megjegyzés: a könnyen érthetö üzenet készitésére a magyar nyelv sajátosságai alapján magyar nyelvü szabályrendszert készítünk. A szabályrendszer várhatóan 2021 decemberében jelenik meg.

\section{A logóhasználat szabályairól tájékródjon} a projekt honlapján. 